\title{
Multilevel Governance and Security: Security Sector Reform in the Central African Republic ${ }^{1}$
}

\author{
Niagalé Bagayoko
}

Abstract This article analyses how the security sector reform (SSR) process in the Central African Republic was defined and implemented between 2008 and 2010, putting emphasis on the interactions between national and international actors. It advocates an approach which consists of expanding the agenda of the traditional multilevel governance approach and which seeks to seize both the top-down and the bottom-up dynamics of decision-making processes. The first objective is to capture the sets of actors and procedures which drove the reform process, and to map out the various levels of government at which decisions are made. Secondly - and more fundamentally - the article aims to capture the intermingling of domestic and international decisionmaking processes, which increasingly overlap and interfere with each other in Southern countries.

\section{Introduction}

In 2008, under international pressure, the Central African Republic (CAR) government accepted the challenge to engage in a holistic and comprehensive security sector reform (SSR) process. This SSR process was launched during a national seminar whose conclusions were officially endorsed by President Bozizé. ${ }^{2}$

Security governance in the CAR involves a wide range of institutional actors embedded in networks with competing agendas and objectives. Both national and international stakeholders are involved in the management of the security sector which, consequently, must be seen as being governed increasingly on multiple levels.

Probing the decision-making processes at stake in security sector reform is particularly important since security policy is traditionally seen as the preserve of sovereign states. One could argue, however, that the Central African State has never been sovereign in the area of security, due to France's historical influence in its security policy after Independence.

Analysing how the SSR process in CAR has been defined and then implemented, this article puts emphasis on the international interactions between institutional actors and networks that may be geographically/territorially situated at different levels of the policymaking process in different places around the world, thus suggesting ways to grasp multi-actor and multisited governance. The issue here is to capture the interactive institutional dynamics at an international level, thus developing a methodological framework that is likely to capture both the top-down and the bottom-up dynamics of decision-making processes.

The multilevel governance (MLG) approach offers a relevant framework in which to investigate these inter-institutional processes, particularly those that weaken the impact of formal arrangements (administrative procedures and legal frameworks), and supplement them with informal dynamics (social network ties, ideas and beliefs).

Studying multilevel security governance requires the adoption of an approach that sidesteps issues of formal sovereignty and focuses instead on where power is actually located, taking into account inter-institutional relationships and the governance arrangements in the particular social context of the country in question - in this case the CAR. The aim is to identify the sets of actors 
and procedures which drive the process, and to map out the various levels at which decisions are made.

More fundamentally, the challenge is to capture the intermingling of domestic and international decision-making processes into networks that increasingly overlap and influence each other in Southern countries. Indeed, what makes the MLG approach different from the traditional one - in which multiple external actors seek to influence (or even control) the actions of sovereign states - is the network idea.

\section{Theoretical background: expanding the multilevel governance approach beyond the analysis of the EU}

Initially, the multilevel governance approach aimed to analyse the changing relationships between actors situated at different territorial levels, both from the public and private sectors, in the context of European integration (Hooghe and Marks 1999). Research based on a multilevel governance approach deals mainly with the complexity of decision-making processes within the European Union (EU) itself.

Recently, the multilevel governance approach has been expanded to emphasise the role of the many actors involved in EU foreign policy, and the ways in which they interact with each other. According to Smith (2003) multilevel governance refers to the sharing of authority across an institutionalised, hierarchically structured set of actors with varying degrees of unity/coherence, commitment to EU norms and power resources. ${ }^{4}$

Most of the research that uses an MLG approach is primarily focused on the decision-making processes in EU circles. These streams of research do not, however, take into consideration the fact that, with governance being 'internationally multi-sited', there is a dire need to integrate local partners into the analysis. Yet, the MLG approach can offer a relevant framework in which to study governance in Southern countries, if complemented and combined with other frameworks of analysis.

\subsection{Dispersed governance: identifying the distribution of power}

Bache (2008a, 2008b) states, 'Multilevel governance is an intuitively appealing concept that offers some insights and informs a research agenda... There is a need for empirical research on multilevel governance that adopts a more critical stance on the issue of power' and is informed by the following requirements:

1 A clear explanation of its assumptions in relation to the nature and location of power and 'a need to explicitly theorise how actors' power is structured... within governance arrangements'. A good starting point is to situate MLG in relation to three aspects of the power and policymaking debate:

(1) decision-making; (2) agenda-setting; and

(3) preference-shaping.

2 Clearer empirical benchmarks for what does and does not constitute multilevel governance. Understanding the distribution of financial, informational, political, organisational and constitutional-legal resources, and the skills with which actors use them is key to explaining policy-decision and outcomeimplementation matters.

3 Explicit theorising on the relationships between actors, governance arrangements and social context (e.g. formal rules, rules of the games, type of network). There is a need to investigate less tangible forms of power by relating governance dynamics to the context (Bache 2008a).

\subsection{Emphasising the importance of policy networks}

What is distinctive about the MLG approach is not only its emphasis on a multiplicity of actors across levels of the system but also of the networks they constitute. This connects to the 'policy network approach'.

Policy networks analysis does not deny the power of classical actors such as national governments but contends that policy outcomes cannot be explained exclusively by national preferences or interests.

The policy network approach states that networks can be more than the sum of their parts and produce outcomes which are not simply a summation of the views of their most powerful members; the influence exercised by the network is seen as an emergent property. The ability of the network to shape outcomes comes from its interactions and the complexities of the ways in which actors influence one another through them. 
Two streams of policy network literature are particularly relevant to this study. The first insists on resources dependencies, the second on the importance of beliefs.

Benson (1982) defines policy networks as a cluster of 'organisations connected to each other by resource dependencies and distinguished from other clusters by breaks in the structure of resource dependencies'. Stephen George (1997) develops a similar perspective, considering that policy networks are characterised by the pattern of resource interdependence between the organisations in the network. To Kenis and Schneider (1989) too, the boundaries of a policy network are not determined by institutions or formal distribution of power but by a mutual recognition of resource dependencies. Resource dependencies are also a major aspect of the famous Rhodes model, which focuses on the way in which networks are structured in a policy sector. ${ }^{6}$

Investigating policy networks in the European Security and Defence Policy and how social network ties and beliefs affect the decision-making process, Mérand asserts a policy domain approach is best suited for a relational understanding of policymaking that focuses not only on governments and formal organisations but also on social relationships and beliefs affinities among organisational actors such as diplomats, parliamentarians, defence experts, etc. (Mérand 2009). ${ }^{7}$

\subsection{Multi-sited governance: bringing the 'policy transfer approach' into the analysis}

Most scholars who refer to the multilevel governance approach have left out the question of the impact that national partners have on the policies supported by international actors. In other words, national actors are treated as being outside the network or in a separate one. The multilevel governance approach has to be deepened and enriched with the burgeoning literature on 'policy transfer'.

Stubbs highlights the need to conceptualise and understand the decision-making processes 'in terms of complex overlapping networks' (2005). To do so, he refers to the 'policy transfer' approach, defined by Dolowitz and Marsh (2000).

Stubbs highlights the importance of taking into account the dimensions of 'policy resistance' and 'resistance strategies of apparently weak groups in the context of asymmetric dependencies'. Using contributions from anthropology he advocates an understanding of how international decision-making processes interact with formal and informal channels of decision at the national level in partner countries. His interest is not just on formal decision-making processes, but also on semi-formal and informal ones.

Stubbs however, has not paid enough attention to the role played by networks per se. The most powerful approach to policy transfer integrating a network analysis is with no doubt the 'external governance approach'. Lavenex (2004) has suggested a framework for analysing the EU's external effects on non-EU member states, whereby the scope and shape of policy transfer is conditioned by existing institutional links between the EU and the other countries, the latter's immediate domestic situation, and the costs of non-adaptation associated with an EU policy. On the one hand, networks can be instrumentalised as alternative instruments of policy transfer, thus compensating for weaknesses of strategic conditionality. On the other hand, their participatory potential is currently hampered by heterogeneous political structures, unequal expertise and policy traditions in countries (Lavenex 2008).

This article will mostly refer to the literature on MLG focused on the EU context. However, some conflict literature has also advocated a global-tolocal approach, whilst some authors have considered how violence and armed groups are networked across national borders (Schlichte and Veit 2007). Likewise, there is an important and fast-growing literature on the hybridity of African states and of their governance arrangements, which has put the stress on multilayered governance and networked power in development/conflict contexts. Bayart (1989) deals with the formal institutions of the modern state exported by the French colonial power, analysing the extent to which African governments have shaped the outcomes and appropriated Western governmental institutions to pursue long-established strategies. Banegas (2003) has analysed the same dynamics at stake in electoral democracies, confirming Bayart's conclusions.

There is also a long tradition of organisation theory, going back to the French sociologist Michel Crozier (1964), which has focused on informal 
networks and forms of power in bureaucracies. Focusing on their respective social systems namely interpersonal relations, group relations, and power relations - Crozier challenged and reexamined Weber's concept of efficient ideal bureaucracy in light of the way institutional bureaucracies have actually developed. Such a theory inspired the way in which Robin Luckham (1971) analysed the micropolitics of military and security institutions in Nigeria.

This article suggests an analysis of the security governance arrangements aimed at capturing the distribution of power in the social context of the CAR, by analysing the kinds of resources that are mobilised by different networks of actors (domestic and international) at every stage of the decision-making process.

To capture multilevel, multi-sited governance, there is a need to focus both on the formulation (agenda-setting and programming) phase and the implementation (managing and monitoring) phase of policymaking. ${ }^{8}$ Indeed, security governance in CAR involved a wide range of domestic stakeholders (national authorities as well as nongovernmental, and non-state actors) and international actors (international organisations as well as other states) intervening along with specific policymaking processes (both formal and informal), which themselves interacted and interfered with each other. Consequently, security governance resulted, to a large extent, from the interactions between the resources mobilised respectively by the international and the domestic networks during the policymaking processes.

I propose to capture power distribution in CAR's security governance by identifying the material and normative resources that were mobilised by international and national actors involved in security governance in the CAR since the SSR process was launched, namely the EU, ${ }^{9}$ France and national stakeholders (both governmental and non-governmental) at (1) the policy formulation phase (agenda-setting and programming), and (2) the implementing phase (managing and monitoring). The aim is to capture both power distribution between and within policy networks.

3 Policy formulation phase: agenda-setting and programming

To identify the distribution of power during the agenda-setting/programming phases, there is a need to identify who provided the guidelines, set the priorities, and defined the general purpose of the SSR process in CAR and to identify who was involved in programming the different stages of the process. Throughout the policy formulation phase, three kinds of resources were primarily mobilised: normative resources, assessment resources and programmatic resources.

\subsection{Normative resources}

Studying normative resources enables one to capture the representation of security that underlies the approach of each set of stakeholders. Normative resources here refer both to values and systems of beliefs as well as the way in which a problem is conceptualised that is, what the problem is thought to be and the range of possible solutions or responses to it that are considered viable. This emphasises the representation of security in a context marked by a plurality of actors with different objectives, strategies and expectations.

3.1.1 Multilateral stakeholders: the central role of the EU

The EU was one of the most important international actors that supported the SSR process in CAR. EU SSR documents explicitly refer to the SSR guidelines (Security System Reform and Governance: Policy and Good Practice) adopted by the Organisation for Economic Cooperation and Development/Development Assistance Committee (OECD/DAC) and translated into political and operational principles in the OECD Handbook on Security Systems Reform: Supporting Security and Justice (OEGD 2007). ${ }^{10}$ The SSR process supported in CAR by the EU appears as an ideal-type illustration of the holistic approach developed by the OECD/DAC, wherein security sector reform seeks to increase partner countries' ability to meet the range of security needs within their societies in a manner consistent with democratic norms and sound principles of governance, transparency and the rule of law. It is important here to note that the SSR concept itself, as framed by the OECD, promotes a multilevel approach of security governance. Furthermore, the OECD/DAC Manual strongly envisages the role that international partners are likely to play when providing support to SSR processes: international donors are seen as an integral part of the multilayered governance system promoted through SSR (OECD 2007: 63-86 and section 8). 
At the EU level, the endorsement of the SSR concept by the European Commission (EC) has clearly been driven by the Directorate General for Development (DG Development, often referred as DG Dev). ${ }^{11}$

Within the Commission, it thus has been the 'development network' (DG Dev and its connections with other development agencies) that has been driving the SSR-related policy. Endorsing a human security-based concept, the DG Dev has increasingly promoted an approach to security focused on individuals' physical security and the protection of their rights. Consequently, the approach the Commission promotes is 'governance-oriented' in the sense that it is centred on good governance and the promotion of human rights, which implies that security can no longer be seen as the preserve of the state but has to involve a wider range of stakeholders.

\subsubsection{Bilateral stakeholders: the role of France ${ }^{12}$}

Since the Independence of the Oubangui-Chari provinces, France has been the main bilateral actor in the Central African Republic and has been deeply involved in the governance of the security sector there. ${ }^{13}$

However, due to the growing accusation of paternalism, neocolonialism and complicity with authoritarian (and the case of the Rwanda 'genocidaire') regimes, France has been eager to obtain a multilateral legitimacy for its interventions on the African continent and has been increasingly integrating its interventions within the EU framework. Charbonneau (2008) provides an interesting analysis of this.

The French security policy in CAR is a perfect example of the process through which French security policy has been modified and adapted to fit into the system of liberal security governance promoted at the EU level. The SSR paradigm as promoted by the EU has given a new legitimacy to the traditional French security policy, especially to the military and technical permanent assistance.

\subsubsection{CAR domestic stakeholders}

Different representations of security reform competed among the Central African Republic's domestic actors. First, the CAR's political actors (governmental authorities, opposition parties and rebel groups) referenced a very traditional vision of security: security reform was seen as a means of building up a security apparatus (essentially a militarised one) that could guarantee the state's legitimate violence and thus ensure political continuity and the hegemonic position of ruling actors. The context of war, which had prevailed in CAR for more than a decade, deepened this tendency. It is extremely important to mention the fact that almost all the influential political actors on the CAR political scene today have been playing a leading role in national politics for decades: most of them have occupied the highest functions (former Presidents of the Republic, Ministers of Defence, Prime Ministers, Chiefs of Staff) before joining the ranks of different rebel outfits or of the opposition. Thus it is possible to identify what can be called a 'ruling elites network', made up of politicians, high-ranking officers and rebel group leaders. Interactions between the members of this network are informed by a subtle game of solidarities as well as rivalries. All these political leaders have considered the military as the best instrument to support their access to power and for 20 years the successive Heads of State have attempted to instrumentalise the armed forces in order to perpetuate their dominant position. In the government's view, SSR mainly - if not exclusively - amounted to reinforcing the military's skills. The role of the police was considered marginal since the armed forces had always been used to perform traditional police work. In sum, the sense of security developed by the CAR's political elites' network fundamentally differed from the normative approach promoted by the OEGD and international actors such as the EU.

Beyond political circles, it is possible to identify two alternative representations of security reform which were widespread among two other sets of Central African actors:

Security actors themselves: the armed forces, police forces (mid-level officers and rank agents) and other security services (intelligence services, customs, water/forest services) form a 'national security network': they developed an approach to security reform that was mostly focused on the ways in which their working conditions and individual financial and social conditions could improve. The most widespread claims among security 
providers themselves were systematic demands for the payment of back pay; regular access to the so-called PGA (Prime Générale d'Alimentation - food allowance); free access to medical care; construction of barracks where families could be accommodated; supply of new equipment; and access to training.

- The population at large: the civilian population, especially in the provinces, has suffered for years from the abuses committed by the armed forces with total impunity (Human Rights Watch 2007) and from their inability to cope with new threats they are confronted with on a daily basis (such as the so-called zaraguinas the road-cutters).$^{14}$ There is also a lot of suspicion towards the police force, which is mainly seen as corrupt and extortionist. Consequently, the populations' definition of security reform was mainly framed in terms of physical safety, which non-state security actors (vigilante groups set up by the villagers themselves) or customary actors (traditional justice providers), were seen as the most likely to provide. The CAR population cannot of course be seen as a network per se: but it undoubtedly saw its own security as better ensured if and when embedded in communitarian and traditional networks. In CAR, a large part of the population relies on a variety of traditional and religious conflictresolution mechanisms other than the formal state systems. International actors increasingly tend to acknowledge the existence and relevance of these systems. However, some of these systems legitimise practices - for instance, the persecution of alleged 'witches' which do not uphold international human rights standards as promoted by the OECD/DAC approach to SSR.

Finally, it is important to mention that, whilst the OECD approach considers the role of civil society as crucial in the politics of security sector reform (see Caparini 2005), in the CAR it is hard to identify a strongly structured civil society. A number of associations (human rights defenders, women's associations) do exist, the most important of which are structured around religious networks, mainly Christian in essence. However, at the time of the reform, such organisations had not formed any constituency nor developed any advocacy actions to represent citizens' views and monitor the activities of state security institutions.

\subsection{Assessment resources}

The agenda-setting phase of the SSR process in CAR sheds light on the important role international experts played in the policymaking process.

A team made up of international (non-African) experts, from a variety of backgrounds (both academic and practitioner) was initially set up to make a comprehensive assessment of the CAR's security apparatus. The team clearly promoted the views and beliefs promoted by the DG Dev and favoured a human security-based approach to SSR. Their assessment was central in defining the agenda: Haas' definition (1992) of an epistemic community as 'a network of professionals with recognised expertise and competence in a particular domain and an authoritative claim to policy-relevant knowledge within that domain or issue-area' perfectly describes the connections that existed between the DG Dev and the external experts in the CAR's SSR process. ${ }^{15}$

In contrast, the influence of Central African nationals in the agenda-setting process was marginal. A National Preparatory Committee, made up of Central African personalities, was set up to prepare the National SSR Seminar. The National Seminar itself formally involved an important number of Central African participants (both from governmental and non-governmental circles). However, most of the Central African stakeholders involved in the assessment process were hardly able to mobilise credible expertise. Seeing the striking lack of national assessment capacities, the international partners finally decided to send an international SSR team from the OECD to train all members of the Preparatory Committee. National stakeholders thus were influenced in developing their own conceptions of security by their incorporation into the international SSR networks. The views of international experts - themselves converted to the human security-based approach to SSR - largely framed the agenda and the two-year timeline of the SSR process.

\subsection{Programmatic resources}

The mobilisation of programmatic resources is meant to identify the priorities, establish a hierarchy between them, and select appropriate resources and funding mechanisms in order to set up a planning programme. The resources for SSR were mobilised by three international actors 
- the EC, the United Nations Development Programme (UNDP) and France - and were combined to put SSR on CAR's agenda: goals, objectives and timelines were defined in order to fit into the Poverty Reduction Strategy.

The identity of the EU institutional actors involved in SSR-related programmes in CAR was, to a large extent, derived from the financial instruments dedicated to external assistance. The Directorate General for External Relations (DG Relex) ${ }^{16}$ and DG Dev were involved in the programming phase of the SSR process in CAR, ${ }^{17}$ as was the EuropeAid office. The role of the 'Brussels-based development network' was thus central.

Another key EC actor in this programming phase was the EU Delegation ${ }^{18}$ in the CAR capital, Bangui, which played a pivotal role, both at the political and technical level, acting as an interface between the Directorates-General in Brussels and the international ${ }^{19}$ and national stakeholders in CAR. This pivotal role sheds light on the major importance - often underestimated - of the EU Delegation in European foreign and security policy decision-making processes. Focusing on processes of knowledge production and implementation, Schlichte and Veit (2007) develop the model of 'coupled arenas' and argue that the 'outcomes of state-building policies have to be "associated with organisational problems and connected ways of perceiving reality within interventionists" camps'. The activities of international agencies active in the field of peace and state-building are occurring in different locations simultaneously and policy outcomes can be better understood when conceived as the results of the interactions between actors in three different arenas, namely: the metropolitan (most of the time Western) headquarters, national base camps (located in the capital of partner/recipient countries) and local offices 'in the bush'. These three different arenas are interactive, for instance through financial resources or staff transfer which are both top-down and bottom-up in essence (e.g. financial resources transferred from the headquarters to the field and knowledge and information acquired locally which are transferred by agents located on the ground).

To better understand the policy outcomes therefore, it is necessary to integrate into the analysis the European decision-making process, actors which are based in partner countries, namely the EU in-country representatives (the EU Delegation) and the representatives of EU member states (the embassies and the cooperation services affiliated to them). In fact, the programmatic phase of the SSR process has also been highly shaped by the interactions between the EU Delegation and France. Being a leading member of the EU - especially with regard to EU Development policy - as well as the major bilateral player in CAR, France has both an 'inside' and 'outside partner' role with the EU delegation, which together with its long experience in the country, has reinforced its influence on EU policy in the CAR. In the programmatic phase, France proved to be eager to see its own bilateral policy integrated into the SSR process. One of its requirements was to have its traditional military and security cooperation network fully associated with the design of the SSR programmes funded by the EC. It also proved eager to ensure that the social interests of the security services were taken into account in the two-year timeline. Whilst the CAR government did not manage to promote the social condition of the security services (excepting those of the presidential guard and other praetorian services), the traditional French cooperation networks have been very efficient in supporting the claims of the CAR security network, on behalf of the 'arms fraternity' (fraternité d'armes).

\subsection{Distribution of power in the policy formulation phase} The OECD/DAC approach to SSR endorsed by the EU fundamentally challenges the statecentric and sovereign conception of security: it aims to broaden the set of actors involved in security policy beyond government circles. Through SSR, the EU in particular and development agencies more generally are fundamentally trying to change power relationships in Southern countries by making policymaking processes more inclusive and accountable. From this point of view, the OECD/EU approach to SSR is an illustration of governance as defined by Marcussen and Torfing (2007) who consider that 'governance implies a decentring of governing away from the state and a pluralisation of actors involved in governing'.

France has both supported and counterbalanced this approach: whilst French diplomatic actors have clearly endorsed the human security-driven agenda, it has also been agreed that the traditional 'French military/security cooperation 
network' would stay fully involved in the definition of the SSR agenda. This network thus acted as a mediator to promote the social claims of the CAR's military staff. But it was also very sensitive to the views of the ruling elite network, seen as the best guarantee of perpetuating a political order conducive to some kind of stability in the region.

Yet, the vision of security promoted through the SSR concept was not in accordance with the vision of security which was most widespread among GAR's political stakeholders, in and out of government. However, CAR political actors were not able to mobilise assessment and programming resources to promote their own conception of security reform, which was primarily seen as a means of reinforcing the military apparatus. Central African actors were not able to mobilise significant expertise and programmatic resources to have a major impact on the formulation phase. The solutions privileged by the CAR population to meet their definition of security (which mostly amount to physical security and in fact are not very concerned with matters of transparency and accountability) were not taken into account.

Consequently, the SSR process was almost exclusively framed by international actors (mainly the European development network and the French coopérants networks). It is difficult to identify any major influence by the national actors.

\section{Implementing phase: managing and monitoring}

To assess the distribution of power in this implementing phase, I will focus on four kinds of resources: institutional, technical, financial, and monitoring.

\subsection{Institutional resources}

Three kinds of institutional resources are considered in the following paragraphs: constitutional, legislative, and decentralised resources. The issue is to determine the extent to which the CAR institutional framework was conducive to democratic security governance as defined by the OECD/EU doctrines. Indeed, it is highly important for SSR processes to be tailored to the institutional regime of the partner country.

The new Constitution of the Central African Republic, adopted by referendum on 5 December 2004, was promulgated on 28 December 2004.
Elaborated on the basis of the previous Constitution of 14 January 1995, this new fundamental law established a semi-presidential regime. The constitutional framework is largely inspired by the French Fifth Republic Constitution, which formally favours the concentration of power in the hands of the Presidency. According to the Constitutions, the President of the Republic, as Supreme Chief of the Armed Forces, is able to define the national defence policy, which is executed by the Minister of the Armed Forces, under the aegis of the Prime Minister. As in most Francophone African countries, these constitutional provisions have resulted in a situation where the security domain is, to a large extent, the exclusive monopoly of the President, assisted by a limited circle of civilian and military advisers (Bagayoko 2010). In addition, since 2003, the President of the Republic has concurrently held the role of Minister of Defence, in violation of Article 23 of the Constitution, which stipulates that the function of the President of the Republic is incompatible with the exercise of any other political function. Under international pressure, the President finally decided to create the post of Minister of State for Defence, which he conferred on his son.

One of the central objectives of the SSR process is the promotion of the role of parliament in the supervision and oversight of the defence and security institutions. In the CAR, the parliament is unicameral: the National Assembly consists of 105 representatives. Between 2005 and 2010, the Central African National Assembly was dominated by representatives associated with President Bozizé. According to Article 61 of the Central African Constitution, the National Assembly is empowered to exercise parliamentary control over the defence and security forces. Two parliamentary committees are in charge of security matters: the 'Defence' Committee, in charge of questions relating to the Forces Armées de Centrafriques (FACA - Central African armed forces) and to the gendarmerie, and the 'Home/Law' Committee, in charge of questions relating to the internal security forces. These Committees are endowed with the power of inquiry and are supposed to control ministerial responsibility through oral or written questions, or can even vote for a censure motion against ministers; they are also supposed to approve and control the defence and security budget and to supervise the 
interventions of the armed and security forces. In practice, however, the parliamentarians do not exercise the powers they are entrusted by the Constitution. In fact, empowering the National Assembly as planned by the SSR process largely amounts to reinforcing the government itself, given that the Central African National Assembly is dominated by parliamentarians belonging to political parties associated with the President. Consequently, most of the members of the Defence and the Internal Affairs Committees belong to parties from the majority group and are very unlikely to launch information enquiries or to adopt legislation that the government does not agree with. It is worth noting as well that it is hard to consider the political parties not affiliated to the presidential majority as opposition groups: most of the members of these parties have participated in one way or another in successive governments of the current regime, confirming the prevalence of a ruling elites network. Nevertheless, the democratic legitimacy of the Central African parliamentarians cannot be denied: indeed, the unquestionably fair legislative elections of May 2005 truly gave the head of state a majority in parliament. Yet, it is also an unquestionable fact that most of the political groups in the National Assembly have been chaired by close relatives of the President.

The SSR process planned to increase the influence of decentralised actors over security governance. The objective was to create zones of defence in order to develop a 'défense de proximité' (defence of proximity): these zones of defence were to coincide with the government of administrative regions and were meant to be managed by the prefects of each zone. The idea was to confer on the prefect the responsibility for coordinating the troops deployed in his prefecture. It was also planned to reinforce the municipal police forces and consequently the power of the mayors who are legally responsible for overseeing those forces. Yet these zones of defence, as well as the regions, are empty shells. Indeed, administrative regions were created on paper and should be headed by governors. ${ }^{20}$ Law 88.005 and Order 88.006 of 5 and 12 February 1988 determine the administrative organisation of CAR and override Laws 64/32 and 64/33 of 20 November 1964. However, both the 1988 orders have been only partially implemented so far. The municipality is a territorial jurisdiction, consisting of villages, districts, areas and neighbourhoods, the territorial limits of which are determined by law. According to the texts, mayors are elected by the city council, which is itself elected for five years. However, no municipal election has ever been organised in the Central African Republic and, at present, mayors are appointed by the central power by decrees or orders. Besides, mayors failing in their duties can be revoked by the President of the Republic. Moreover, in spite of the 1988 laws, there were no prefects in the regions (provinces) until 2003: instead, military governors managed administration and police problems. Consequently, it was doubtful that increasing the responsibilities of decentralised actors as envisioned by the SSR process would result in a more balanced management of the security sector.

\subsection{Financial resources}

As one of the poorest countries in the world, the Central African state clearly could not mobilise the financial resources needed to fund a holistic SSR process. In fact, funding was almost exclusively provided by the international community.

However, international donors only had partial control over the resources they provided to fund the SSR process. The CAR government was largely able to control the way in which the financial resources dedicated to the SSR process were used, particularly those dedicated to the defence sector. The budget of the armed forces appears to be only symbolic. It is extremely difficult for parliamentarians and oversight bodies (auditor general, inspector general, ombudsman, Audit Account Court) to obtain information about the realities of the defence budget. A number of international experts (both contracted by multilateral donors and by France) also confessed that the question of the defence budget remained totally mysterious to them: the issue was too sensitive for them to dare ask questions (interviews with representatives of international donors, Bangui, April 2008).

This situation partly explains why one of the key objectives of the SSR process was to introduce transparency and sound principles in the management of the security sector, particularly by favouring the development of auditing capacities. However, most of the institutions and procedures that international partners tried to support were deprived of any significant 
influence over the budgeting process. For instance, whilst the Audit Account Court was seen by international donors as a key independent oversight body, the magistrates from this jurisdiction confessed to being very reluctant to control the expenses of the security sector, tacitly considered as the exclusive monopoly of the Head of State (interviews with representatives of international donors, Bangui, April 2008). Furthermore, the Audit Account Court was not given any means by the government or the parliament to fulfil its missions. Similarly, the parliament has voted on security budgets as requested by the government without being given any information regarding its content.

In fact, it appears that even external funds cannot be sufficiently controlled through the national budget system: the audit and control procedures are not functioning and the budgeting process is in fact largely controlled not by the government as such, but exclusively by the Presidency.

\subsection{Technical resources}

International experts were very important players in the implementation process through the set up of the multidisciplinary SSR advisory team, responsible for assisting the Central African stakeholders in the implementation of the reforms. This team was jointly supported by the EU and the UNDP. France was able to integrate its own national experts into the EUfunded team. Those experts - who were also involved in the formulation phase as mentioned above - were very close to the Central African military and security elites. It was also a means for France to share some costs of its bilateral defence and security cooperation.

Regarding domestic expertise, most of the national experts who were designated to implement the SSR process (especially the "point focaux' responsible for coordinating the reforms in each area of the security sector) belonged to the 'first proximity circle' of the President. They largely implemented the technical options designed by the EU-funded team or by French technical advisors.

\subsection{Monitoring and Evaluation (M\&E) resources}

Monitoring resources are mobilised to review progress and achievement and to evaluate the impact of the SSR process. In the CAR's SSR process, monitoring resources were exclusively mobilised by international actors: the EU Delegation was responsible, in cooperation with EuropeAid, for coordinating all the assistance provided by different Directorate Generals of the Commission (Directorate General for External Relations; Directorate General for Development; EuropeAid) and for evaluating and auditing the reform process. The experts mobilised for M\&Erelated tasks were more or less the same individuals who had previously been mobilised in the assessment phase and who belonged to the Brussels-based development network.

\subsection{Distribution of power in the implementation phase}

The implementation phase of the CAR's SSR process was clearly dominated by the government and more precisely by the Presidency, which proved able to control both an important part of the financial resources (which were almost exclusively provided by international partners) and the institutional resources located in non-governmental policymaking circles (especially the parliamentarians and the decentralised actors).

Today, as an International Crisis Group (ICG 2007) report succinctly underlines, the real power is monopolised by the President of the Republic and his close relatives. ${ }^{21}$ Interinstitutional relationships in CAR are underpinned by a complex system of processes and interfaces of a non-institutional nature. Informal links and structures of power based on such factors as ethnic group, family and informal political connections count as much as the formal institutional mechanisms (Bigo 1988). Put another way, inter-institutional relationships in the CAR's social context are working 'via a range of subjective interfaces and partnerships of which the formal mechanisms are either a component thereof or are, alternatively, merely the formal expression of these power relations' (Williams 2005). ${ }^{22}$ Governance is networked in the CAR but the informal social and political solidarity networks do not necessarily contribute to the democratic governance of the security sector: the actors that the international stakeholders thus sought to mobilise are in fact controlled by the government, which did not have the same agenda or at least the same definition of security as the one underlying the SSR concept. 
Consequently, international stakeholders such as the EU only had limited influence on the implementation of the SSR process - essentially exercised via their financial and monitoring resources. The most influential international actor in the implementation phase was clearly France through its technical, military and security advisors.

\section{Conclusion}

The case study of the SSR process in the Central African Republic shows how decision-making competencies are shared amongst a variety of actors, internationally located at different territorial and institutional levels and organised around different networks. Investigating the kind of power distribution at stake in the SSR process clearly suggests that there is a growing dispersion of power in the CAR's security governance.

The policy networks at stake in the security sector reform process in the CAR were namely:

- The European Union development community, which promoted a governance approach to security based on the human security paradigm and formed an epistemic community made up of experts from some member states and civil servants from the European Commission;

- The French traditional security cooperation network, which promoted a more classical perspective of security assistance and whose fundamental objective was stability. Through this network, France was present at almost all levels of the policymaking process (both in the formulation and implementation phase);

- The CAR's ruling elites network which adhered to a very traditional approach to SSR. Whilst unable to enforce such a perspective during the formulation phase of the SSR process, this network was able to dominate the implementation process and control both the financial resources and the domestic actors supposed to supervise use of the security forces.

New international players such as the EU (and the UNDP) were undoubtedly able to set up new priorities and conceptions of security in CAR. Their influence over the outcomes was in fact largely limited to the policy formulation phase. The implementation phase, however, was mostly dominated by the Central African executive power, which was the only actor able to mobilise and control both the local resources and, to a lesser extent, some of the international resources.

The approach to security sector reform, as promoted by multilateral actors, is mainly framed in terms of technical questions of coordination and political questions of democratic governance. Such an approach interfered with the CAR's value systems and patronage networks, which were largely dominated by the ruling political elite. One of the main problems of the EU SSR concept, itself derived from the OECD approach, is that it is too often based on theoretical models that are drawn from Western political science and which are of limited use in understanding how the security sector actually works in practice in African states. It is then necessary to take into consideration the microsocial dynamics and the diverse forms of organisation and civil control, which are unconstrained by formal legality, and which involve other social processes and interfaces. A wide range of informal procedures shape decision-making in the CAR, and interfere with the norms and procedures that are promoted by multilateral actors. These kinds of informal processes, often rooted in kinship, customary and patronage networks but also in shadow-political networks, co-exist with the state's formal decisionmaking structures, inspired by the Weberian rationalist organisational model (inherited from French colonial rule) and increasingly by the decentralised mechanisms that multilateral actors are attempting to introduce via the SSR process.

Furthermore, the actors that can be seen as an immediate alternative, or rather a complement to the presidential security apparatus, are presently not located in the check-and-balance institutions inspired by the Western institutional model. These actors can be seen as belonging to two categories: first, the vigilante and selfdefence groups (the so-called 'local forces' and 'archers') established by the villagers in the provinces; secondly, traditional and customary justice institutions. However, these actors, even if meeting some expectations of the population, do not always intervene on behalf of the democratic and human rights standards promoted by the SSR concept.

The multilevel governance approach - when complemented by a 'policy/social network approach' and by the policy transfer approach, which stresses informal, loose structures, network 
ties and belief affinities that extend across, and beyond, hierarchies - is well-equipped to grasp such processes. Indeed, the value that is added by a multilevel governance approach is that it goes beyond formal organisational arrangements, and formal decision-making mechanisms, recognising complexity far more than traditional politicoadministrative models do. The multilevel governance approach can provide a relevant framework to study the ways in which domestic security governance in some African countries is reshaped by the interactions of the heterogeneous norms, standards and procedures underlying international and domestic decisionmaking processes, which thus contribute to challenging the state-centric definition of sovereign security governance.

The question of the state-centric notion of sovereignty does matter, particularly in the

\section{Notes}

1 This article is based on field research which was carried out between 2008 and 2010.

2 Crucial Steps: Security Sector Reform in CAR, report published with the support of the UNDP, http://hdptcar.net/blog/wpcontent/uploads/2008/06/undp_ssr_report_ may_2008.pdf (accessed 29 March 2012).

3 For a critical overview of the literature dealing with a governance approach to European integration, see Jachtenfuchs (2001).

4 From this perspective, Michael Smith's (2003) approach to multilevel governance is related to the 'actor-centred institutionalist approach to policy research' proposed by Scharpf (1997) and derived from the study of politicalorganisational fields. Scharpf's approach focuses on the 'policy domain concept', defined as the set of groups and organisations active in formulating, advocating and selecting policy options. The basic idea of the 'policy domain' concept is that 'the solutions to a given policy problem must be produced by the interdependent choices of a plurality of policy actors with specific capabilities and with specific perceptions and preferences regarding the outcomes that could be obtained'.

5 A lot of criticism has been formulated against the policy network approach, for example: Thatcher (1998) and Koenig (1998), who consider that policy network is only 'a useful metaphor, but does not constitute a model or theory'. Richardson (2000) considers that context of a policy aimed at reforming a sector that is traditionally at the core of state institutions. But investigating the SSR process in CAR through a multilevel governance approach allows one to incorporate sovereignty and the informal realities of multiple actors and processes, thus enabling one to draw conclusions about the kind of security governance that is emerging in the Gentral African context. The security sector, traditionally seen as the preserve of the sovereign state, is no longer centrally governed, but increasingly multilevel governed. However, this situation does not mean that the Central African state has lost its prominence in the realm of security. At present, local or indigenous procedures as well as political and patronage networks controlled by the ruling elite are likely to prevail over technical procedures and inclusive governance arrangements promoted by international actors. ${ }^{23}$

policymaking at the EU level is too fluid for stable networks to exist or persist.

6 In the Rhodes model (Rhodes 1997a, 1997b) the following factors are emphasised: resource dependencies; the relative stability of network memberships; and the relative insularity and autonomy of networks.

7 This sentence is quoted from a research project currently led by Frédéric Mérand: 'The European Security and Defence Policy Domain: Network Ties, Beliefs System, and Decision-Making', Conseil de Recherches en Sciences Humaines du Canada.

8 Marks (1993) has taken into account both of these phases when analysing European integration in his first conceptualisation of multilevel governance.

9 The UNDP is also a major stakeholder in the CAR's SSR process. This article, however, specifically focuses on the EU's role.

10 The first version of the concept was presented in 1998 by the then British Development Minister, Clare Short, who presented SSR's purpose as 'to ensure the efficient and effective provision of state and human security within a framework of democratic governance'. The OECD/DAC has deepened and conceptualised this initial British approach to SSR.

11 Weiler (2009) has subtly analysed the progressive assimilation of the SSR concept by the European Commission in general and the DG Dev in particular. 
12 Many French specialists of French African policy have thoroughly analysed the dynamics of this post-colonial policy. For a

comprehensive literature review of this topic, see Bagayoko (2003 and 2010).

13 France signed an official defence agreement with the country which allowed French forces to be permanently stationed in CAR. After the 1997 withdrawal of its military forces (following two waves of mutinies within Central African barracks), France maintained a contingent of 220 soldiers and, in October 2006, strengthened this contingent by sending supplementary soldiers when a rebel group launched an attack against the government. Besides direct military assistance, French servicemen have also participated in training Central African servicemen, whilst French technical advisers work on a daily basis within the Central African Ministries (Defence, Interior, Customs, Justice, etc.). Since 2003, the military cooperation between France and the Central African Republic has been characterised by the application of an emergency plan, which is based on the reorganisation of the Central African armed forces (FACA) and its gendarmerie.

Significant support has also been provided to the police forces.

14 The zaraguinas consist of Central Africans and nationals of neighbouring countries, particularly Chadian. They attack mainly travellers on roads and widen their raids to villages, taking advantage of the quasiabsence of security authorities in the northern regions. They particularly target breeders, mainly Peulh nomadic communities, whom they force to sell their cattle to pay a ransom in exchange for their children held as hostages. The attacks of zaraguinas have forced some communities to set up self-defence units in their villages.

15 The approach developed by Ruth Hanau Santini (2006) should be integrated into analysis of the cognitive influence that experts deployed in Southern partnercountries can have on policymaking. Hanau Santini advocates an approach based on the relationship between French and German foreign policy epistemic communities (composed of experts as well as policymakers) to analyse the Common Foreign and Security Policy (CFSP) and the elaboration of the European Security Strategy.
16 In 2001, DG Relex created a 'Conflict and Peace Building Unit' in charge of coordinating the Commission efforts in conflict prevention.

17 Indeed, the framework for EC-led SSR processes is the Country/Regional Strategy Paper (CSP or RSP), which sets out the main objectives and sector priorities for cooperation for a seven-year term (six years for ACP (Groupe des Etats d'Afrique, des Caraïbes et du Pacifique (Group of African, Caribbean and Pacific state) countries). More specifically, SSR-related programmes are included within National or Regional Indicative Programmes (NIP or RIP) which detail specific activities and expect results corresponding to the strategic objectives of the CSP/RSP. DG Dev and DG Relex have overall responsibility for developing CSPs, in theory in close collaboration with partner countries.

18 The EU Delegation in CAR is part of the External Service of the European Commission (Directorate General for External Relations). However, the Delegation does not only represent the Commission, but the EU as a whole. In 2003 the EU Delegation's responsibilities expanded considerably as a consequence of the devolution policy adopted by the Commission in 2000. From then on, the Delegation has covered all aspects - from identification to implementation and evaluation - of the EU external assistance and aid programme.

19 It is important to mention that the SSR process in CAR is also shaped by interactions between the different multilateral stakeholders. Since 2005, international donors' coordination in partner countries is meant to be based on the principles of the Paris Declaration on Aid Effectiveness. The UNDP is the major multilateral partner of the EU in the SSR process. Consequently, one of the most important tasks of the EU Delegation is to coordinate the EG SSRrelated programmes with those of the UNDP, in order to clearly define roles and responsibilities, and to avoid ambiguity about divisions of labour that could hamper implementation.

20 Currently, the Central African Republic is divided into 16 prefectures, each placed under the responsibility of a prefect. These prefectures are divided into 66 subprefectures, then into 175 municipalities. Moreover, there are 8,800 villages or districts. 
21 Contrary to his predecessors, since he seized power in 2003, General Bozizé cannot really be accused of pursuing an ethnic policy in the army. Recently, to satisfy the international community (one of the major objectives of security sector reform being to introduce a better balance in the ethnic composition of the armed and security forces), the Deputy Minister of Defence launched a recruitment drive, with 500 soldiers being recruited from across the whole country. However, when interviewed, servicemen (as well as gendarmes, policemen, and customs officers) admitted that only the Gbaya (the President's ethnic group) have authority, whilst the Yakoma (the ethnic group of former President Kolingba) are marginalised. All the highest positions are occupied by members of the Gbaya group.

\section{References}

Bache, I. (2008a) 'Researching Multi-level Governance', paper presented to the Governance and Sustainability Seminar Series, University of Westminster, 24 January

Bache, I. (2008b) Europeanization and Multi-level Governance: Cohesion Policy in the European Union and Britain, Lanham: Rowman and Littlefield

Bagayoko, N. (2010) Security Systems in Francophone Africa, IDS Research Report 64, Brighton: IDS

Bagayoko, N. (2003) Afrique: Les Strategies Française et Américaine, Paris: l'Harmattan

Banegas, R. (2003) La Démocratie À Pas De Caméléon - Transition et Imaginaires Politiques Au Bénin, Paris: Collection Recherches Internationales, Khartala

Bastian, Sunil and Hendrickson, Dylan (2008) State Responsiveness to Public Security Needs: The Politics of Security Decision-Making - Review of Methodology and Lessons for Future Research, CSDG Paper 13, June

Bayart, J.F. (1989) L'État en Afrique: La Politique du Ventre [The State in Africa: Politics of the Belly], Paris: Fayard

Benson, J.K. (1982) 'A Framework for Policy Analysis', in D. Rogers, D. Whetten and associates, Interorganizational Coordination: Theory, Research and Implementation, Iowa: State University Press

Bigo, D. (1988) Pouvoir et Obéissance en Centrafrique [Power and Obedience in the Central African Republic], Paris: Khartala

Caparini, M. (2005) 'Enabling Civil Society in Security Sector Reconstruction', in A. Bryden and H. Hänggi (eds), Security Governance in Post
22 Only a few researchers have investigated the security decision-making processes in Southern countries (Bastian and Hendrickson 2008).

23 According to Yves-Alexandre Chouala (pers. comm.) 'Historically and practically, sovereignty has never been absolute and in this sense, the Central African Republic has never been a full sovereign state in the security field. But, if one agrees that sovereignty is more often conceived as the room for manoeuvre and autonomy that a state conserves in a constrained and relational context, the Central African Republic probably remains a sovereign security state'.

Conflict Peace Building, Geneva, Switzerland: Geneva Centre for the Democratic Control of Armed Forces

Charbonneau, B. (2008) France and the New Imperialism: Security Policy in Sub-Saharan Africa, Aldershot: Ashgate Publishing

Crozier, M. (1964) The Bureaucratic Phenomenon, Chicago: University of Chicago Press

Dolowitz, D. and Marsh, D. (2000) 'Learning from Abroad: The Role of Policy Transfer in Contemporary Policy Making', Governance: An International Journal of Policy and Administration 13.1: 5-23

George, S. (1997) Policy Networks and the European Union, European Union Studies Association (EUSA), Biennial Conference 1997 (5th), http://aei.pitt.edu/2590/ (accessed 1 October 2010)

Haas, P. (1992) 'Introduction: Epistemic Communities and International Policy Coordination', International Organization 46.1: 1-35

Hanau Santini, R. (2006) 'The Evolution of CFSP: What has been the Role and Impact of French and German Foreign Policy Epistemic Communities?', paper presented at the annual meeting of the International Studies Association, Town and Country Resort and Convention Center, San Diego, USA, 22 March

Hooghe, L. and Marks, G. (1999) 'The Making of a Polity: The Struggle over European Integration', in H. Kitschelt, P. Lange, G. Marks and J.D. Stephens (eds), Continuity and Change in Contemporary Capitalism, Cambridge: Cambridge University Press 
Human Rights Watch (2007) Central African Republic: State of Anarchy. Rebels and Exactions Against the Civil Population, New York: HRW: 19.14

ICG (2007) Central African Republic: Anatomy of a Phantom State, Africa Report 136, 13 December, International Crisis Group

Kenis, P. and Schneider, V. (1989) 'Policy Networks as an Analytical Tool for Policy Analysis', paper for conference at Max Planck Institute, Cologne, 4-5 December

Koenig, T. (1998) 'Introduction: Modeling Policy Networks', Journal of Theoretical Politics 10.4: 387-8

Jachtenfuchs, M. (2001) 'The Governance Approach to European Integration', Journal of Common Market Studies 39: 245-64

Lavenex, S. (2008) 'A Governance Perspective on the European Neighbourhood Policy: Integration Beyond Conditionality?', Journal of European Public Policy 15.6: 938-55

Lavenex, S. (2004) 'The External Dimension of Europeanization: The Case of Immigration Policies', Cooperation and Conflict 39.4: 417-43

Luckham, R. (1971) The Nigerian Military: A Sociological Analysis of Authority and Revolt (1960-1967), Cambridge: Cambridge University Press

Marcussen, M. and Torfing, J. (2007) Democratic Network Governance in Europe, Basingstoke: Palgrave Macmillan

Marks, G. (1993) 'Structural Policy and Multilevel Governance in the EC', in A.W. Cafruny and G.G. Rosenthal, The State of the European Community, Volume 2: The Maastricht Debate and Beyond, Boulder CO: Lynne Rienner

Mérand, F. (2009) The European Security and Defence Policy Domain: Network Ties, Beliefs System, and Decision-Making, Research Paper, Montreal: Conseil de Recherches en Sciences Humaines du Canada
OECD (2007) OECD Handbook on Security Systems Reform: Supporting Security and Justice, Paris: Organisation for Economic Co-operation and Development

Rhodes, R.A.W. (1997a) 'Policy Networks: A British Perspective', Journal of Theoretical Politics 2.2: 293-317

Rhodes, R.A.W. (1997b) Understanding Governance, Buckingham: Open University Press

Richardson, J. (2000) 'Government, Interest Groups and Policy Change', Political Studies 48.5: 1006-25

Scharpf, F. (1997) Games Real Actors Play: ActorCentred Institutionalism in Policy Research, Boulder CO: Westview Press

Schlichte, K. and Veit, A. (2007) Coupled Arenas: Why State-building is so Difficult, Berlin: Humbolt University Working Papers Micropolitics

Smith, M. (2003) 'The Framing of European Foreign and Security Policy: Towards a Postmodern Policy Framework?', Journal of European Public Policy 10.4: 556-75

Stubbs, P. (2005) 'Stretching Concepts Too Far? Multi-Level Governance, Policy Transfer and the Politics of Scale in South East Europe', Southeast European Politics 6.2

Thatcher, M. (1998) 'The Development of Policy Network Analyses: From Modest Origins to Overarching Framework', Journal of Theoretical Politics 10.4

Weiler, Q. (2009) The European Union and Security Sector Reform in Africa: A Leader in Theory, a Laggard in Reality?, Bruges Regional Integration and Global Governance Papers 1 Williams, R. (2005) 'African Armed Forces and the Challenge of Security Sector Reform', Journal of Security Sector Management 3.2 